\title{
BUSINESS CHARACTERISTICS, TAX ADMINISTRATION AND TAX COMPLIANCE BY SMES IN NIGERIA
}

\author{
Abidemi C. Adegboye ${ }^{1 *}$, Ifeoluwa Alao-Owunna ${ }^{2}$, Monday I. Egharevba ${ }^{1}$ \\ ${ }^{1}$ Department of Economics, Adeyemi College of Education, Ondo, Nigeria \\ ${ }^{2}$ Department of Economics, Adeleke University, Ede, Nigeria \\ *cornabi@gmail.com
}

\begin{abstract}
This study evaluates the relative impacts of tax administration and business characteristics on the tax compliance behaviour of small scale businesses in Nigeria. The role of tax education as an effective tax administration strategy is also considered. Results show that tax education stimulates small businesses tax compliance behaviour, a result that is robust for both business taxes and personal taxes. It is also found that overall tax administration system in Nigeria does not have significant impact on tax compliance among small businesses in Nigeria due to inefficiencies and corruption in the system. Business ownership structure, registration status, and management qualification/experience are all found to promote tax compliance by small businesses in Nigeria.
\end{abstract}

Keywords: Tax education, tax efficiency, Tax compliance, SMEs

JEL Classification: H21, H25, L53

\section{Introduction}

Mobilization of tax revenue has become a crucial economic and policy objective of government at all levels in Nigeria in recent years. In the same vein, the challenge of tax evasion and attendant revenue losses are real at both national and state levels. Evasion has been known to be strengthened by non-compliance to tax laws, ease of going underground by businesses and institutional or administrative weaknesses in the tax system. To weather these challenges, the public sector in Nigeria focused on indirect taxation as the main source of tax revenue. It has however been argued that the high dependence of the tax system on indirect taxes tends to weaken fiscal applications for an economy like Nigeria (Baunsgaard and Keen, 2005). Increasing direct tax revenue largely depends on government's ability and efficiency in tax collection. In doing this, governments can do little, especially in the short run, to change the structural basis of the tax revenue. It can however alter other factors that influence tax revenue, such as economic policies that affect businesses, strengthening institutions, and improving the quality of tax administration.

In the past two decades, business and personal taxation has received more attention in terms of tax obligations in Nigeria, especially at the state and local government levels. To meet such obligations, the small and medium scale enterprises (SMEs) have faced the biggest struggles in Nigeria (Atawodi \& Ojeka, 2012). There is often a dilemma for the government between allowing small businesses to develop and the collection of taxes. The case for providing tax preferences to SMEs is often based on the role of SMEs in the economy, particularly in terms of their contribution to employment, job creation and innovation. The challenges that arise therefore include the issues of tax base definition and clarification in Nigeria, tax education, and the administration of tax structure in Nigeria. Apparently, the highlighted issues involve efficiency of tax administration as well adequate analysis of who the tax payers are. This is useful when the internal revenue board seek to

*Corresponding author: Abidemi C. Adegboye 
mobilize taxpayers' awareness regarding tax matters as well targeting the highly informal groups of taxpayers that are in the SME sector in the country.

This study considers the relative importance of tax administration and SME business characteristics as driving factors of tax compliance in Nigeria. These are particular areas that have not received much research attention on the research on tax compliance in Nigeria. Specifically, it evaluates how tax compliance by small businesses in Nigeria is influenced by the business characteristics and the tax administration system in Nigeria. To meet these objectives, the study is divided into four sections including the introduction. The methodology employed in the study is presented in section three while the empirical analysis is performed in the fourth section. Concluding remarks are made in the final section.

\section{Brief Literature Review}

The factors that explain the desire of tax payers to comply with the provisions of the tax system have been considered extensively in literature, including psychological, legal, economic, and environmental. In a popular study on broad factors that explain tax compliance, Wentworth and Rickel (1985) argued that psychological factors are important in determining whether an individual evades a tax system or not. In particular, their study found that an "individual's feelings of equity and sense of norm commitment" actually has more impact on desire for tax compliance than the effects of sanctions and legal actions. Recent findings also appear to support this early study on compliance. Djawadi and Fahr (2013) employed controlled experimentation to investigate the impact of citizens' trust in authorities on tax compliance. They found that tax compliance is higher when trust is built between the taxpayers and authorities through transparency on public expenditures participation in expenditure processes. The power of tax authorities was shown to be of little effect as long as trust is in place. Thus, according to this line of research, tax compliance is essentially to be evaluated from the perspective of the tax-payers' disposition (Mettler, 2011; Lamberton, De Neve \& Norton, 2014; Jimenez \& lyer, 2016). In this study, the payers' perspective is taken into cognizance, although we focus on the business characteristic which can form a strong position from which the payers' psychological disposition is measured.

Other studies have considered the role of tax institutions, administrative capacities, and environment on the platform of 'enforcement or services paradigm' of tax compliance determinants (Alm, Cherry, Jones \& McKee, 2010). The argument is that when the authorities provide effective leadership in the tax system, the tax payers are obliged to comply with the rules. Alm et al. (2010) find that a tax system fraught with uncertainties results in less compliance in tax filing and the reporting, and that more information from the tax agency tends to improve tax return filing in the US. For Cameroon, Akinboade (2015) found that high registration costs and time-consuming processes corruption perception in the tax system, excessive compliance hurdles, unstable administrative policies, and lack of willingness of tax personnel to provide timely and adequate information tend to promote tax non-compliance in the country. In this study, tax administration system in Nigeria is considered as also exerting effects on tax compliance by SMEs. Thus, this study extends the literature by combining the roles of psychological and authority-based factors in explaining tax compliance in Nigeria. Few studies have embarked on such combination effects (e.g. Sapiei, Kasipillai \& Eze, 2015, for Malaysia).

\section{Research Methodology}

The principal method common to this aspect of research is empirical method with application of the survey research design. This method entails the use of quantitative, statistical or regression techniques in evaluating the research issues or problems. The study is based on micro level data from the World Bank Enterprise Survey data collected in Nigeria between 
April 2014 and February 2015. The Enterprise Surveys (ES) is a World Bank project that collects objective data based on firms' experiences and enterprises' perception of the environment in which they operate. The Enterprise Surveys collect information from a representative sample of the non-agricultural formal private economy. In addition to collecting information on the business environment the surveys collect information on the characteristics of the firms interviewed. Consequently, the data collected provides a description of the representative private firm in the country and also an estimate of how some of the attributes of the average firm are distributed across the population of firms. For Nigeria, this project was expanded with increased geographic coverage during fieldwork. It began as a 9-state exercise and 10 more states were added for a total of 19 states.

\subsection{Model Specification}

The modelling in this study is based on the objectives of the study. Apparently, modeling enterprise tax compliance outcome will have to take an experimental procedure which is the focus in this section. The Causal effect of tax administration and business characteristics on individual business tax compliance can be empirically investigated by observing an agent is compliance capacity $y_{i}$ and tax education $t_{i}$. Following de Grip and Sauermann (2012), the observed outcome can thus be written as:

$$
y_{i}=y_{i}\left(t_{i}\right)=t_{i} \cdot y_{i}(1)+\left(1-t_{i}\right) \cdot y_{i}(0)
$$

where $y_{i}(1)$ and $y_{i}(0)$ denote compliance in the treated (with effective tax administration) and untreated states, respectively. The randomised assignment of agents to the treatment and control groups ensures the independence of treatment status and potential outcomes. The average treatment effect, $T$ (the effect of tax administration) can be estimated by performing a linear regression of individual is tax compliance $y_{i}$ on a treatment dummy ti which is defined as being one in the with perceived positive tax administration, and zero otherwise:

$$
y_{i}=\alpha_{i}+\gamma_{k}+\tau d_{i t}+\beta X_{i}+u_{i}
$$

where $\alpha_{i}$ are individual fixed effects to account for individual heterogeneity remaining despite the experimental design. $X_{i}$ are covariates that are assumed to be independent from the treatment status $d_{i}$ such as business environment, and $u$ is an idiosyncratic error term.

Given the objectives of the study, the covariates $X_{i}$ include tax administration (tax_admin) and business characteristics (bus_character) variables. Since there are possible multicollinearity effects between tax administration and business characteristics effects in a single equation, two equations are specified to identify the effects of tax education, tax administration, and other business characteristics on tax compliance by small businesses in Nigeria. The equations are:

$$
\begin{aligned}
& y_{i}=\alpha_{i}+\gamma_{k}+\tau d_{i t}+\beta \text { tax_admin }_{i}+u_{i} \\
& y_{i}=\alpha_{i}+\gamma_{k}+\tau d_{i t}+\beta \text { bus_character } r_{i}+u_{i}
\end{aligned}
$$

Equation (3.3) represents the effects of tax education and tax administration on tax compliance, while equation (3.4) shows the effects of business characteristics on tax compliance.

\subsection{Variables in the model}

Tax compliance. This shows the level of compliance of businesses to their tax obligations. In this study, tax compliance is captured by two items in the ES questionnaire

i. Have you ever paid less in business taxes than you should?

ii. Have you ever paid less in personal taxes than you should?

Tax education. In the study, tax education is measured by the level of awareness of the businesses on their tax obligations. It is measured by the ES questionnaire items that show number of visits of tax official to educate businesses on tax administration and obligations. 
Tax administration. This represents the efficiency of tax system. It determines the ease with which individual business pay their tax obligation. An inefficient tax administration will hinder tax compliance. For this variable, certain items in the ES questionnaire that measure time spent demand of gift by tax officials and obstacles of tax system are used.

Business characteristics. These are the salient factors in the business that could influence its tax obligations. These include ownership patterns, number of employees, registration of business, etc.

\subsection{Method of Analysis}

A major issue arises from the estimation of the models in this study. The data is heterogenous, especially along individual firm lines. Hence, the simple OLS estimate of the relationships will yield biased results. It should be noted that the determination of the variables above is based on qualitative data obtained from the survey questionnaire. Following OECD (1994) and Greene (2004), the Maximum Likelihood econometric form of the model is written as:

$$
\begin{aligned}
\operatorname{Pr}\left[C O M P L_{j}=1 / X_{j}\right] & =\frac{1}{1+\exp \left(-\alpha_{0}-\beta_{0} x_{j}\right)} \\
\operatorname{Pr}\left[\operatorname{COMPL}_{j}=0 \mid X_{j}\right]= & 1-\operatorname{Pr}\left[\operatorname{COMPL_{j}}=0 \mid X_{j}\right] \\
& =\frac{\exp \left(-\alpha_{0}-\beta_{0} X_{j}\right)}{1+\exp \left(-\alpha_{0}-\beta_{0} X_{j}\right)}
\end{aligned}
$$

where the $X_{j}$ 's are the explanatory variables and $\alpha_{0}$ and $\beta_{0}$ are unknown parameters to be estimated. According to Greene (2003), the Logit regression model is a type of regression analysis used for predicting the outcome of a binary dependent variable (a variable which can take only two possible outcomes, e.g. "yes" vs. "no" or "success" vs. "failure") based on one or more predictor variables. Logistic regression attempts to model the probability of a "yes/success" outcome using a linear function of the predictors. Specifically, the log-odds of success (the logit of the probability) is fit to the predictors using linear regression. Logistic regression is one type of discrete choice model, which in general predict categorical dependent variables - either binary or multi-way.

\section{Empirical Analysis}

\subsection{The Data}

The responses for the overall study are summarized for the SMEs in Nigeria based on overall firm characteristics and performance. The summary of the data in terms of firm characteristics reported in Table 1 shows that the average age of the surveyed firms for Nigeria is 15.9. Most of the businesses in the survey are largely owned by domestic participation and very few of the firms (1.9 percent) are owned by governments. This indicates that government participation in owning and running small manufacturing firms is quite low in Nigeria. In the survey also, 76.7 percent of the firms surveyed in Nigeria are sole proprietorship businesses. This is also reflected in the 95.2 percent proportion of the surveyed firms being owned by the largest owner. This result shows that most of the firms are privately owned and operated in Nigeria. 
Table 1: Summary Statistics of Firm Characteristics

\begin{tabular}{|l|c|}
\hline Indicator & Percentage \\
\hline Age of the establishment (years) & 15.9 \\
\hline Proportion of private domestic ownership in a firm (\%) & 70.7 \\
\hline Proportion of private foreign ownership in a firm (\%) & 3.1 \\
\hline Proportion of government/state ownership in a firm (\%) & 1.9 \\
\hline Proportion of a firm held by the largest owner(s) (\%) & 95.2 \\
\hline Percent of firms with legal status of publicly listed company & 3.3 \\
\hline $\begin{array}{l}\text { Percent of firms with legal status of privately held Limited Liability } \\
\text { Company }\end{array}$ & 3.1 \\
\hline Percent of firms with legal status of Sole Proprietorship & 76.7 \\
\hline Percent of firms with legal status of Partnership & 8.6 \\
\hline Percent of firms with legal status of Limited Partnership & 5.5 \\
\hline
\end{tabular}

Source: World Bank Enterprise Survey, 2014

We also consider the indicators on the tax compliance and tax administration based on the responses from the ES survey questionnaire. In Table 2, the response outcomes for some administrative issues on the tax system, as it affects the small scale enterprises, is presented. In the result, the bribery index, which is the proportion of gifts or informal payments made to officials during public transactions was 26.0 percent in 2014 . The number of visits with tax officials for a particular tax transaction is also shown to be 2.34 on average in 2014. A very low proportion of the businesses chose tax administration or tax rate as the biggest obstacle to their operations. This reveals that tax system is not the most debilitating factor against small business development in Nigeria. However, 14.1 percent of the businesses identified tax administration as a major constraint to their businesses. This shows that though tax administration has improved, the tax system is still a major factor inhibiting business. This also shows that the ease of paying tax in Nigeria by small businesses has not improved. In terms of tax officials attitude, the Table shows that 25.9 percent of the businesses are expected to give gifts to tax officials over the course of their interactions. Apparently, tax officials make things difficult for the businesses to pay tax by increasing the cost through corruption.

Table 2: Tax Administration and Compliance Outcomes

\begin{tabular}{|l|c|c|}
\hline Indicator & $\mathbf{2 0 0 7}$ & $\mathbf{2 0 1 4}$ \\
\hline $\begin{array}{l}\text { Bribery index (\% of gift or informal payment requests during public } \\
\text { transactions) }\end{array}$ & 30.1 & 26.0 \\
\hline Number of permanent full-time workers & 16.2 & 15.8 \\
\hline Number of visits or required meetings with tax officials & 3.0 & 2.3 \\
\hline $\begin{array}{l}\text { Percent of firms choosing tax administration as their biggest } \\
\text { obstacle }\end{array}$ & 0.3 & 1.6 \\
\hline Percent of firms choosing tax rates as their biggest obstacle & 2.2 & 5.9 \\
\hline Percent of firms expected to give gifts in meetings with tax officials & 22.9 & 25.9 \\
\hline $\begin{array}{l}\text { Percent of firms expected to give gifts to public officials "to get } \\
\text { things done" }\end{array}$ & 40.9 & 55.3 \\
\hline Percent of firms identifying tax administration as a major constraint & 13.7 & 14.1 \\
\hline Percent of firms identifying tax rates as a major constraint & 20.9 & 18.5 \\
\hline Years of the top manager's experience working in the firm's sector & 10.0 & 12.5 \\
\hline
\end{tabular}

Source: World Bank Enterprise Survey, 2014 
To further report the responses of the survey, certain items from the questionnaire are highlighted with their responses from the businesses in the survey. In Table 3, the responses on tax compliance on business taxes are shown. The respondents responded to the question on whether they had paid less in business taxes than they should before. Only 17.6 percent of the respondents agreed to have done this before, while 78.3 percent indicated that they have not paid less than the expected business taxes before. This reveals rather high level of tax compliance by businesses.

Table 3: Have you ever paid less in business taxes than you should have in this business?

\begin{tabular}{|l|l|l|l|}
\hline & Freq. & Percent & Cum. \\
\hline Don't know (spontaneous) & 25 & 0.94 & 0.94 \\
\hline Does not apply & 84 & 3.16 & 4.10 \\
\hline Yes & 467 & 17.57 & 21.67 \\
\hline No & 2,082 & 78.33 & 100.00 \\
\hline Total & 2,658 & 100.00 & \\
\hline
\end{tabular}

Source: World Bank Enterprise Survey, 2014

The level of education of top management in a business can influence the level of tax performance. In Table 4, the educational qualifications of managers in the businesses are reported. The highest proportion of the managers have either completed the secondary school (28.7 percent) or graduated from the university (27.3 percent). Also, 13 percent of the managers have some university training, thus making the managers well educated to be able to handle tax activities in the businesses quite well.

Table 4: What is the highest level of education of the Top Manager?

\begin{tabular}{|l|c|c|}
\hline & Freq. & Percent \\
\hline Don't Know & 82 & 3.09 \\
\hline No Education & 46 & 1.73 \\
\hline Primary School & 121 & 4.56 \\
\hline Started but did not complete secondary & 91 & 3.43 \\
\hline Secondary School & 760 & 28.66 \\
\hline Vocational Training & 297 & 11.20 \\
\hline Some university training & 351 & 13.24 \\
\hline Graduate degree (BA, BSc etc.) & 724 & 27.30 \\
\hline Masters of Business Administration (MBA) & 127 & 4.79 \\
\hline Other post graduate degree (Ph.D, Masters) & 53 & 2.00 \\
\hline Total & 2,652 & 100.00 \\
\hline
\end{tabular}

Source: World Bank Enterprise Survey, 2014

\subsection{Regression Analysis}

In this section, the results of the cross-sectional data estimates of the models specified in the previous Chapter are reported and analysed. The focus of the analysis is actually on the goodness of fit statistics as well as the coefficients' results which will help provide the basis for the tests of hypotheses in the study. 


\subsubsection{Effects of Tax Education, Administration and business characteristics on Business Tax Compliance}

In this section, the results for business tax compliance are analysed. In the result in Table 5, the business characteristics factors that explain tax compliance are shown. The goodness of fit outcome of the results are quite impressive, with the Wald Chi-Square test probability less than 0.01 . From the result, all the coefficients (apart from number of employees) passed the significance test at the 1 percent level. The results from the individual coefficient test shows that all the variables actually have significant impacts on the dependent variable. Thus, the proportion of business owned by the top manager has a positive and significant impact on tax compliance. The higher the proportion of the business that is owned by the top manager, the higher the level of tax compliance by the businesses. Thus, small businesses run by owners tend to comply more with their tax obligations in Nigeria.

Table 5: Regression results for Business Characteristics and Business Tax Compliance

\begin{tabular}{|l|c|c|c|}
\hline Variable & Coef. & z-value & Prob \\
\hline Proportion of Ownership & 0.005 & 8.30 & 0.000 \\
\hline Registered & 0.366 & 12.75 & 0.000 \\
\hline Manager experience & 0.008 & 4.44 & 0.000 \\
\hline Manager qualification & .089 & 11.56 & 0.000 \\
\hline Manager ownership & .149 & 7.84 & 0.000 \\
\hline No of employees & -0.002 & -3.59 & 0.002 \\
\hline Number of obs & \multicolumn{3}{|c|}{763} \\
\hline F(6, 757) & \multicolumn{3}{|c|}{0.024 .1} \\
\hline Wald test Prob > chi &
\end{tabular}

Source: World Bank Enterprise Survey, 2014

Registration also appears to matter for business tax compliance by the SMEs. From the result, the coefficient is positive and shows that businesses that are registered before starting activities tend to be more tax compliant. Manager experience and qualification also have significant positive impacts on business tax compliance. From the results, the more the experience of top manager or the higher the educational qualification, the more complaint such businesses will be. Only the number of employees has a significant negative impact on business tax compliance. This implies that the more the employees a small business has, the less compliant it tends to be in terms of business taxes. Apparently, small businesses that have more employees tend to report less in terms of tax obligations.

Still on taxes paid on businesses, Table 6 shows the estimation results of the impact of tax education and administration on tax compliance. In terms of individual tax education and administration factors on tax compliance, the results show that only the coefficients of time spent with tax officials and inspection of businesses for tax education coefficients are significant at the 5 and 1 percent levels respectively. The coefficients of the other variables failed the significance test at the 5 percent level. Only that of gifts given to tax officials passed the test at the 10 percent level. 
Table 6: Tax Education, Tax Administration and Tax Business Compliance

\begin{tabular}{|l|c|c|c|}
\hline & Coef. & z-value & Prob. \\
\hline Time-spent & 0.0011 & 2.48 & 0.013 \\
\hline Education inspection & 1.759 & 32.5 & 0.000 \\
\hline Inspection frequency & 0.001 & 0.27 & 0.787 \\
\hline Inspection gift & -0.049 & -1.90 & 0.057 \\
\hline Obstacle - tax rate & 0.007 & 0.45 & 0.653 \\
\hline Obstacle - tax admin & -0.014 & -0.88 & 0.381 \\
\hline Obstacle - quality of tax & -0.014 & -1.21 & 0.226 \\
\hline Number of obs & \multicolumn{3}{|c|}{1287} \\
\hline F(7, 1280) & \multicolumn{3}{|c|}{0.046} \\
\hline Wald test Prob $>$ chi $^{2}$ &
\end{tabular}

Source: World Bank Enterprise Survey, 2014

The results reveal that the time spent with tax officials in sorting out tax issues tends to improve tax compliance. Since this time spent with officials entail tax education, it shows that the more time spent on tax education and clarifications, the more compliant businesses tend to be with their tax obligations. Moreover, inspection of businesses by tax officials also provide education to the small businesses. This also tends to improve tax compliance by the businesses. This shows that tax education is a strong factor in promoting tax compliance by small businesses in Nigeria. For the tax administration factors, the results show that only corruption in terms of gifts requested by tax officials has slight negative impacts on tax compliance in Nigeria. Thus, the more gifts the businesses have to give to officials, the less compliant they become in their tax obligations. The obstacles posed by tax administration and quality of tax system both have negative effects on tax compliance, but these effects are rather negligible since their coefficients fail the significance test at the 10 percent levels.

\subsubsection{Effects of Tax Education, Administration and business characteristics on Personal Tax Compliance}

The behaviour of personal tax compliance in the face of tax education and other factors was examined in this section. In Table 7, the impact of business characteristics on personal tax compliance is shown. Like the previous results, the model possesses impressive goodness when the Wald test is considered. In particular, the results show that the coefficients of all the variables, except number of employees are significant at the 1 percent level. That of number of employees fail the significance test even at the 10 percent level, revealing that number of employees does not affect personal tax compliance of business tax owners.

For the significant coefficients, the results show that all the business characteristics factors positively affect tax compliance. Thus, the more proportion of the business that the manager controls, the earlier the registration of the business or the higher the manager qualification and experience, the higher will be the tax compliance at the individual level. 
Table 7: Personal Tax Compliance Model - I

\begin{tabular}{|l|c|c|c|}
\hline Variable & Coef. & z-value & Prob \\
\hline Proportion of Ownership & 0.0043 & 7.36 & 0.000 \\
\hline Registered & 0.414 & 13.97 & 0.000 \\
\hline Manager experience & 0.009 & 4.40 & 0.000 \\
\hline Manager qualification & 0.0789 & 9.86 & 0.000 \\
\hline Manager ownership & 0.154 & 7.77 & 0.000 \\
\hline No of employees & -0.001 & -0.58 & 0.560 \\
\hline Number of obs & \multicolumn{3}{|c|}{728} \\
\hline F( 6, 722) & \multicolumn{3}{|c|}{0.0000} \\
\hline Wald test Prob $>$ chi $^{2}$ & \multicolumn{3}{|c|}{} \\
\hline
\end{tabular}

Source: World Bank Enterprise Survey, 2014

Finally, the impact of tax education and administration on personal tax compliance is shown in Table 8. In the result, the tax education and administration factors that explain tax compliance are shown. The coefficients of inspection and education as well as that of gifts given to tax officials are significant while the other coefficients fail the test. The coefficient of education during inspection has a significant positive impact on personal tax compliance while that of gifts requested by tax officials has significant negative impact on tax compliance. These results are similar to those of the business tax model.

Table 8: Personal Tax Compliance-tax education and administration effects

\begin{tabular}{|l|c|c|c|}
\hline Variable & Coef. & z-ratio & p-value \\
\hline Time-spent & 0.001 & 1.69 & 0.090 \\
\hline Inspection & 1.831 & 73.58 & 0.000 \\
\hline Inspection frequency & -0.004 & -1.75 & 0.081 \\
\hline Inspection gift & -0.016 & -2.90 & 0.004 \\
\hline Obstacle tax rate & -0.019 & -1.23 & 0.217 \\
\hline Obstacle tax admin & -0.011 & -0.62 & 0.536 \\
\hline Obstacle quality of tax & -0.003 & -0.28 & 0.780 \\
\hline Number of obs & \multicolumn{3}{|c|}{1485} \\
\hline F(7,1478) & 4237.57 \\
\hline Wald test Prob > chi ${ }^{2}$ & 0.0 \\
\hline
\end{tabular}

Source: World Bank Enterprise Survey, 2014

\subsubsection{Robustness Checks: Heteroskadasticity test}

Another robustness test conducted for the models is the test of heteroskedasticity given that data used are cross-sectional. Woodridge (2004) has noted that such investigation gives direction on the appropriate estimation technique to be used in emotion. Apparently, a highly heteroskedastic set of observations may lose efficiency properties when estimated with the ubiquitous OLS technique. It should be noted that the Breusch-Pagan-Godfrey tests are used for the analysis. Only the F-value for the test results for each of the models in the study is reported in Table 9. The F-statistics for all the results (apart from that of the pooled data and regulators) all have probability values less than 5 percent. This means that the null hypotheses of no heteroskedasticity for each of the models is accepted. The non-significance of the test statistics indicates the presence of homoscedasticity in data series for each of the models. This again, confirms the robustness of the estimates from the models. 
Table 9: Test of Heteroskedasticity Results

\begin{tabular}{|l|c|c|}
\hline Model & F-statistic & Prob. \\
\hline Business characteristics (business tax) & 1.583 & 0.18 \\
\hline Business characteristics (personal tax) & 1.355 & 0.26 \\
\hline Tax education and admin (business tax) & 0.662 & 0.65 \\
\hline Tax education and admin (personal tax) & 1.062 & 0.39 \\
\hline
\end{tabular}

Source: World Bank Enterprise Survey, 2014

\section{Conclusion and Recommendations}

In this study, the relative outcomes of tax administration and business characteristics as determining factors of the compliance behaviour of the tax payment by small scale businesses in Nigeria is examined. The general outcome of the study reveals that effective tax administration that involves tax education has far-reaching positive effects on tax compliance. In particular, the results show that tax education stimulates small businesses tax compliance behaviour. This positive effect is robust for both business taxes and personal taxes. Indeed, awareness creation on the knowledge of tax fillings, sanction and penalties as well as simplified tax system tends to improve compliance in Nigeria. Also, it has been shown that overall tax administration system in Nigeria does not have significant impact on tax compliance among small businesses in Nigeria. Though tax administration and efficiency have improved, such improvement has not reflected in tax compliance by these businesses in Nigeria. Moreover, business characteristics were shown to have strong positive effects on tax compliance in Nigeria. Ownership structure, registration status and start-off as well as management qualification and experience are all factors that tend to promote tax compliance by businesses in Nigeria.

Tax issues constitute strong consideration for businesses in Nigeria, especially in the era of increased drive for more revenue by government. There is often a dilemma for the government in terms of allowing small businesses to grow and develop and the collection of taxes. Based on the findings of this study, it is recommended that government should consider the characteristic of noncompliant taxpayers, and therefore review current tax policies to build good relationships with taxpayers in seeking to improve general tax compliance level and reduce the compliance burden, especially on small businesses. Moreover, reducing the compliance burden of small business taxpayers may necessitate reducing complexity of the different tax laws or introducing the types of simplification measures discussed above. It also relates to ensuring that more formal regulations, such as the procedures regarding filing, record keeping requirements, procedures for appeal or payment delays, are not unnecessarily complex. An effective tax system for small businesses is a system in which policy, legislation, compliance strategies and taxpayer services are carefully aligned. Such a system is the most likely to reduce compliance burdens for these businesses, promote their compliance and lower costs for the tax administration.

The empirical analysis in this study limited tax administration to issues of corruption perception and ease of making tax obligations by the businesses. It is however clear that broad administrative policies and tax legislation are essential components of the tax system. This study has not considered these aspects, and they form veritable backgrounds for future studies using macro datasets. 


\section{References}

Akinboade, O.A. 2015. Correlates of tax compliance of small and medium size businesses in Cameroon. Managing Global Transitions 13(4), pp. 389-413

Alm, J., T. Cherry, M. Jones and M. McKee 2010. Taxpayer information assistance services and tax compliance behavior. Journal of Economic Psychology, pp. 577-586.

Atawodi, O.W. and S.A. Ojeka 2012. Factors that affect tax compliance among small and medium enterprises (SMEs) in North Central Nigeria. International Journal of Business and Management. 7(2), pp. 87-96.

Baunsgaard, T. and M. Keen 2005. Tax Revenue and (or?) Trade Liberalisation, IMF Working Paper No WP/05/112.

Djawadi, B.M. and R. Fahr 2013. The Impact of Tax Knowledge and Budget Spending Influence on Tax Compliance. IZA Discussion Paper No. 7255.

Greene, W.H. 2004. Econometric Analysis (5th Ed). Prentice Hall, New Jersey, USA.

De Grip, A. and J. Sauermann 2012. The Effects of Training on Own and Co-worker Productivity: Evidence from a Field Experiment. The Economic Journal, 122(560), 376-399. Jimenez, P. and G.S. Iyer 2016. Tax compliance in a social setting: The influence of social norms, trust in government, and perceived fairness on taxpayer compliance. Advances in Accounting, 34, pp. 17-26.

Lamberton, C., J. De Neve and M.I. Norton 2014. The Power of Voice in Stimulating Morality: Eliciting Taxpayer Preferences Increases Tax Compliance. Harvard Business School Working Paper 14-106 April, 23.

Mettler, S. 2011. The submerged state. Chicago, IL: The University of Chicago Press OECD 1994. Taxation and small businesses. Paris: OECD.

Ponorîcă, A.G. and A.H. Al-Saedi 2015. The importance of taxation systems for SME tax compliance. Proceedings of the 9th International Management Conference, "Management and Innovation for Competitive Advantage", November 5th-6th, Bucharest, Romania.

Sapiei, N.S., J. Kasipillai and U.C. Eze (2014). Determinants of tax compliance behaviour of corporate taxpayers in Malaysia. eJournal of Tax Research,12(2), pp. 83-409.

Wentworth, D.K. and A.U. Rickel 1985. Determinants of tax evasion and compliance. Behavioural Sciences and the Law, 3(4), pp. 455-466.

\section{Bio-note}

Abidemi Cornelius Adegboye is a lecturer in the Department of Economics, Adeyemi College of Education, Ondo in Nigeria. His research area is Development Economics with focus on institutions, fiscal policy and labour markets.

Ifeoluwa Alao-Owunna is a lecturer at the Adeleke University, Ede, Nigeria where she teaches Development Economics. She is currently a PhD student at the Benson Idahosa University, Benin City, Nigeria. Her areas of interest are Development Economics, business policy and international trade.

Monday Egharevba is a lecturer at Adeyemi College of Education, Ondo, Nigeria. His areas of research interest include microeconomic foundations of business organisations, Development Economics, and mathematics of Economics. 